Article

\title{
Effects of Brassinosteroids on Photosynthetic Performance and Nitrogen Metabolism in Pepper Seedlings under Chilling Stress
}

\author{
Ping Yang ${ }^{1}$, Yu Wang ${ }^{2}$, Jie Li ${ }^{1, *(1)}$ and Zhonghua Bian ${ }^{2, *(\mathbb{C})}$ \\ 1 College of Life Science and Technology, Honghe University, Honghe 661100, China; gsau123@163.com \\ 2 School of Animal, Rural and Environmental Sciences, Brackenhurst Campus, Nottingham Trent University, \\ Nottingham NG25 0QF, UK; wangyu985@yeah.net \\ * Correspondence: zhonghua.bian@ntu.ac.uk (Z.B.); gsau23@126.com (J.L.); Tel.: +44-(0)115-848-5284 (Z.B.); \\ +86-(0)873-369-8575 (J.L.)
}

Received: 11 November 2019; Accepted: 28 November 2019; Published: 3 December 2019

\begin{abstract}
To investigate the effects of brassinosteroids on plant growth and nitrogen metabolism in pepper seedlings under chilling stress, pepper seedlings with three true leaves were foliar pretreated with $0.1 \mu \mathrm{M}$ exogenous 24-epibrassinolide (EBR) before carrying out chilling stress for 7 days. The results showed that perapplication of EBR mitigated the chill-induced decrease in plant growth via maintenance of a high net photosynthetic rate $\left(A_{n e t}\right)$, maximum quantum efficiency $\left(F_{v} / F_{m}\right)$, and photochemical quenching coefficient (qP). Exogenous EBR markedly increased the levels of partial free amino acids (proline, arginine, aspartic acid, and glycine) and promoted nitrogen metabolism through increasing the activities of nitrate reductase (NR), glutamine synthase (GS), glutamate synthase (GOGAT), and glutamate dehydrogenase (GDH) in the leaves of pepper seedlings under chilling stress. The effect of exogenous EBR on the content of reactive oxygen species was also investigated. Pretreatment with EBR reduced the accumulation of hydrogen peroxide $\left(\mathrm{H}_{2} \mathrm{O}_{2}\right)$ and superoxide anion $\left(\mathrm{O}_{2}^{--}\right)$, and concomitantly alleviated membrane lipid peroxidation of pepper leaves under chilling stress. These results suggest that foliar pretreatment of EBR has a positive effect on improving the chilling tolerance of pepper seedlings via maintaining a high photosynthetic capability and enhancing the nitrogen metabolism.
\end{abstract}

Keywords: amino acids; ammonium nitrogen; Capsicum annuum L.; nitrate metabolism enzymes; photosynthesis; reactive oxygen species

\section{Introduction}

In winter and early spring, chilling stress is a critical threat restricting the growth and nutrition quality improvement of vegetables produced in protected facilities [1,2]. To feed an ever-increasing global population, it is important to develop an adaptive way to enhance the chilling stress tolerance of crops, thereby minimizing the chill-induced yield loss [3]. It is well known that the damage caused by chilling stress has given rise to the disturbance of many physiological metabolic processes of plants, particularly photosynthesis [4]. Furthermore, nitrogen metabolism is another important physiological process that is sensitive to low temperature stress [5,6]. In plants, there is a closed relationship between nitrogen metabolism and photosynthetic capability [7]. Photosynthesis not only provides carbon skeletons but also supplies reduction energy for nitrogen metabolism [8]. Approximately $25 \%$ of the energy generated by photosynthesis can be used for nitrate reduction [9]. Thus, nitrate is mainly assimilated in plant leaves. In addition, the key enzyme activity of nitrate reduction-nitrate reductase (NR) activity is modulated by the photosynthetic electron transport chain [10]. Therefore, maintaining high photosynthetic capability 
under chilling stress will have a profound effect on nitrogen metabolism and the improvement of nutrition quality in vegetables under chilling stress.

Reactive oxygen species (ROS) play a vital role in plant growth, development, and interaction with biotic and abiotic stresses. As an important regulatory and signaling element in a variety of cellular processes, ROS are constantly produced during the course of photosynthesis and respiration [11]. Chilling stress disrupts plant photosynthesis and induces the overproduction of ROS, including hydrogen peroxide $\left(\mathrm{H}_{2} \mathrm{O}_{2}\right)$ and superoxide radicals $\left(\mathrm{O}_{2}{ }^{-}\right)$. In general, the excessive accumulation of ROS is the main cause of lipid peroxidation, the death of plant cells [12] and the inhibition of photosynthesis and nitrogen assimilation [13]. Brassinosteroids (BRs), as a new type of plant hormone, play a vital role in regulating plant growth and development. This class of phytohormones is represented by more than 60 compounds that have been isolated or detected from more than 100 plant species, from algae to angiosperms, revealing their ubiquitous distribution in the plant kingdom. Since being discovered in 1970, extensive research has proved that BRs modulate a broad range of plant developmental and physiological responses, such as the elongation and division of plant cells, the regulation of photosynthesis, and tolerance to biotic and abiotic stresses [2,14,15]. Exogenous application of 24-epibrassinolide (EBR) could alleviate the inhibition of photosynthesis induced by drought [16], salty stress [17], and low temperature stress [18]. We previously reported that exogenous EBR mitigates chilling stress by enhancing the autoxidation system [19]. Furthermore, exogenous EBR reduces the content of ROS in suspension cells of alpine mustard under chilling stress, protects the integrity of the cytoplasmic membrane, and mitigates the damage caused by chilling stress [20,21]. In plants, light-responsive carbon fixation strongly coordinates with nitrogen assimilation, which enables homeostatic maintenance of the carbon-nitrogen balance in different environments [22]. However, the responses of EBR-induced chilling tolerance concerning photosynthesis and nitrogen metabolism remain to be fully understood.

Therefore, the aim of this study was to investigate the response of the photosynthetic system and nitrogen metabolism in pepper (Capsicum annuum L.) seedlings to exogenous EBR under chilling stress. The results of this study could provide guidance for increasing the yield and quality of peppers produced during the cold season.

\section{Materials and Methods}

\subsection{Growth Conditions and Treatment}

Pepper (Capsicum annuum L. var. Xiangyan 16\#) seeds were sown in seedling trays with commercial substrate and grown in an environment-controlled growth chamber. The light intensity, photoperiod, and day/night temperature were $300 \mu \mathrm{mol} \mathrm{m}{ }^{-2} \mathrm{~s}^{-1}, 12 \mathrm{~h}$, and $28 / 18^{\circ} \mathrm{C}$, respectively. The light sources were delivered by cool fluorescent lamps (Philips T5). After full development of the three leaves, similarly sized pepper seedlings were transplanted into plastic pots $(10 \mathrm{~cm}$ in diameter, one plant per pot) containing a mixture of peat and vermiculite $(2: 1, v / v)$ and grown in the same growth chamber for another 7 days. Prior to being treated with different temperatures $\left(28 / 18^{\circ} \mathrm{C}\right.$ or $\left.15 / 5^{\circ} \mathrm{C}\right)$ and under different light conditions, these seedlings were sprayed with $0.1 \mu \mathrm{M}$ EBR (Sigma-Aldrich, St. Louis, $\mathrm{MO}, \mathrm{USA}$ ) or with the solution used for preparing the EBR working solution (double-distilled water containing $0.05 \%$ Tween-20 as a surfactant) according to our previous studies [23]. These plants were presprayed 3 times with an interval of $24 \mathrm{~h}$. The spray volume was $2 \mathrm{~mL}$ per plant each time. To prepare a $0.1 \mu \mathrm{M}$ EBR working solution, EBR was dissolved using ethanol and then diluted using distilled water containing $0.05 \%$ Tween-20. There were four treatments in the present study. In the first two treatments, plants were grown in a growth chamber with a light intensity and day/night temperature of $300 \mu \mathrm{mol} \mathrm{m}{ }^{-2} \mathrm{~s}^{-1}$ and $28 / 18^{\circ} \mathrm{C}$, respectively. In this growth chamber, these plants, presprayed with distilled water containing the same concentration of ethanol, $0.05 \%$ Tween-20 and $0.1 \mu \mathrm{M}$ EBR, were used as controls (Contr), while plants sprayed with $0.1 \mu \mathrm{M}$ EBR were referred to as Contr + EBR. For the other two treatments, plants were grown in another growth chamber with a day/night temperature of $15 / 5^{\circ} \mathrm{C}$ (day/night) to carry out chilling stress. In the two chilling stress treatments, plants presprayed 
with distilled water containing the same concentration of ethanol and $0.05 \%$ Tween- 20 and with $0.1 \mu \mathrm{M}$ EBR were represented as Chill and Chill + EBR, respectively. To eliminate the excess light energy accumulation caused by high light intensity under low temperature conditions, the light intensity for chill-treated plants was decreased from 300 to $100 \mu \mathrm{mol} \mathrm{m}^{-2} \mathrm{~s}^{-1}$ as described by Hu et al. [24] and Shu et al. [6]. The details of these treatments are summarized in Table S1.

\subsection{Plant Growth and Biomass Measurement}

After being treated for 7 days, nine plants were randomly selected from each treatment to determine the plant height, stem diameter, and biomass determination. To measure fresh weight (FW), plants were weighed after being washed with distilled water. After FW measurement, plants were dried in an oven at $85^{\circ} \mathrm{C}$ for $72 \mathrm{~h}$ before dry weight (DW) determination. The method described by Dickson et al. [25] was used to calculate the index of seedling quality as $Q I=$ (stem diameter/plant height) $\times$ DW.

\subsection{Gas Exchange and Chlorophyll Fluorescence Measurement}

After being treated for 7 days, the third youngest and fully expanded leaves of plants from each treatment were used to determine gas exchange using a portable photosynthesis system (Li-6400, Li-COR Company, USA). The rapid light response curve was measured by 13 light intensities (corresponding to the following light intensities: 1800; 1500; 1200; 1000; 800; 500; 300; 200; 150; 100; 50; 25 ; and $0 \mu \mathrm{mol} \mathrm{m} \mathrm{m}^{-2} \mathrm{~s}^{-1}$ ). The temperature and $\mathrm{CO}_{2}$ concentration in the leaf chamber were set at $25^{\circ} \mathrm{C}$ and $380 \mu \mathrm{mol} \mathrm{mol}^{-1}$, respectively. The actinic light of the leaf chamber was supplied by a red and blue LED light source ( $10 \%$ blue, $90 \%$ red). The light response curve data were fitted using a nonrectangular hyperbola of Thornley [26] by the nonlinear fitting procedure NLIN in the Sigmaplot software (Version 12.3, Systat Software Inc., San Jose, CA, USA) to calculate dark respiration $\left(\mathrm{R}_{\mathrm{d}}\right)$ and the maximum gross photosynthetic rate $\left(\mathrm{A}_{\max }\right)$ :

$$
\mathrm{A}_{\text {net }}=\frac{\alpha \cdot \mathrm{PPFD}+\mathrm{A}_{\max }-\sqrt{\left(\alpha \cdot \mathrm{PPFD}+\mathrm{A}_{\max }\right)^{2}-4 \cdot \theta \cdot \mathrm{PPFD} \cdot \mathrm{A}_{\max }}}{2 \cdot \theta}-\mathrm{R}_{\mathrm{d}}
$$

where $\alpha$ is the light-limited quantum efficiency and $\theta$ is the scaling constant for the curvature.

The $\mathrm{CO}_{2}$ response (A-Ci) curve was conducted as described by Trouwborst et al. [27]. A modified version of the Farquhar, von Caemmerer, and Berry ( $\mathrm{FvCB}$ ) model [28] was employed to fit the A-Ci data. The method described by Sharkey et al. [24] and Trouwborst et al. [29] was used to estimate the potential rate of electron transport under saturating light $\left(\mathrm{J}_{\max }\right)$ and the maximum velocity of Rubisco for carboxylation $\left(\mathrm{V}_{\mathrm{cmax}}\right)$.

After gas exchange measurement, the same leaves were used to monitor chlorophyll fluorescence using a pulse-modulated fluorometer (FMS-2, Hansatech, Norfolk, UK). The maximum quantum efficiency in the dark $\left(\mathrm{F}_{\mathrm{v}} / \mathrm{F}_{\mathrm{m}}\right)$ was monitored after these leaves were dark-adapted in the leaf chamber for at least $30 \mathrm{~min}$. An actinic light source $\left(600 \mu \mathrm{mol} \mathrm{m}{ }^{-2} \mathrm{~s}^{-1}\right)$ was applied to obtain Fs (steady-state fluorescence yield), followed by a second saturation pulse that was applied for $0.7 \mathrm{~s}$ to obtain $\mathrm{F}_{\mathrm{m}}{ }^{\prime}$ (light-adapted maximum fluorescence). The minimal fluorescence in the light $\left(\mathrm{F}_{\mathrm{o}}{ }^{\prime}\right)$ was measured when the actinic light was turned off in the presence of far-red light. The photosystem II (PSII) quantum yield $\left(\Phi_{\mathrm{PSII}}\right)$ and the efficiency of excitation capture by open PSII centers at a steady state $\left(\mathrm{F}_{\mathrm{v}}{ }^{\prime} / \mathrm{F}_{\mathrm{m}}{ }^{\prime}\right)$ were determined according to the method of Genty et al. [30], while the photochemical quenching coefficient (qP) was calculated according to the method of Kramer et al. [31]. The methods described by Hussain and Reigosa [32] and Bian et al. [33] were employed to calculate excessive energy that had accumulated in PSII as:

$$
\mathrm{E}=(1-\mathrm{qP}) \times \mathrm{F}_{\mathrm{V}}^{\prime} / \mathrm{F}_{\mathrm{m}}^{\prime}
$$


The relative deviation from full balance between both photosystems, $\beta / \alpha-1$, was calculated from the equation $(1-\mathrm{f}) / \mathrm{f}$ according to Li et al. [34]. $\beta$ and $\alpha$, representing the photon activity distribution coefficients of PSII and PSI, were determined as:

$$
\begin{aligned}
& \beta=1 /(1+\mathrm{f}) \\
& \alpha=\mathrm{f} /(1+\mathrm{f}),
\end{aligned}
$$

where $f$ is defined as the degree of openness of the PSII reaction center and was calculated from the following equation:

$$
\mathrm{f}=\left(\mathrm{F}_{\mathrm{m}}-\mathrm{F}_{\mathrm{s}}\right) /\left(\mathrm{F}_{\mathrm{m}}-\mathrm{F}_{\mathrm{o}}\right)
$$

\subsection{Chlorophyll Content Determination}

The chlorophyll content of pepper leaves under different treatments was spectrophotometrically determined [35]. Briefly, leaf samples $(100 \mathrm{mg})$ were extracted in $10 \mathrm{~mL}$ of $80 \%(v / v)$ acetone in a dark environment at $4{ }^{\circ} \mathrm{C}$ until the leaf tissues turned white. The absorbance monitored at 470 , 645 , and $663 \mathrm{~nm}$ was used to measure the contents of chlorophyll a (Chl a), chlorophyll b (Chl b), and carotenoids.

\subsection{Determination and Histochemical Localization of $\mathrm{H}_{2} \mathrm{O}_{2}, \mathrm{O}_{2}-\cdot$ and Lipid Peroxidation}

The lipid peroxidation in plant leaves was represented as the accumulation of malondialdehyde (MDA) according to the method of Yang et al. [36]. Briefly, leaf tissue was ground using thiobarbituric acid and boiled at $100{ }^{\circ} \mathrm{C}$ for $20 \mathrm{~min}$. The extracts were centrifuged at $15,000 \mathrm{~g}$ for $10 \mathrm{~min}$ after being cooled at room temperature. The absorbance of the extracts determined at 450, 532, and $600 \mathrm{~nm}$ was used to calculate the MDA content. The contents of $\mathrm{H}_{2} \mathrm{O}_{2}$ and $\mathrm{O}_{2}{ }^{-}$in plant leaves were spectrophotometrically determined as described by Alexieva et al. [37] and Elstner and Heupel [38]. The absorption coefficient of $0.28 \mu \mathrm{M}^{-1} \mathrm{~cm}^{-1}$ was used to calculate the $\mathrm{H}_{2} \mathrm{O}_{2}$ content. The rate of $\mathrm{O}_{2}{ }^{-\cdot}$ in leaves was calculated according to the standard $\mathrm{NaNO}_{2}$ concentration gradient.

Nitroblue tetrazolium (NBT) staining and 3, 3-diaminobenzidine (DAB) staining were used to conduct histochemical localization of $\mathrm{H}_{2} \mathrm{O}_{2}$ and $\mathrm{O}_{2}{ }^{-\cdot}$ as described by Khokon et al. [39]. The detection of lipid peroxidation was performed by staining fresh collected leaves in Schiff's reagent for $60 \mathrm{~min}$ until a pink color appeared according to the method of Pompella et al. [40].

\subsection{Determination of Nitrate Nitrogen and Ammonium Nitrogen Concentrations}

The concentration of $\mathrm{NO}_{3}{ }^{-}$was measured spectrophotometrically [41]. Leaf tissue (0.5 g) was ground with $10 \mathrm{~mL}$ of Millipore-filtered water and then boiled in a water bath for $30 \mathrm{~min}$. After being centrifuged at $2000 \times \mathrm{g}$ for $15 \mathrm{~min}, 0.1 \mathrm{~mL}$ of the supernatant was mixed with $0.4 \mathrm{~mL}$ of $5 \%$ salicylic- $\mathrm{H}_{2} \mathrm{SO}_{4}$ and left to react for $20 \mathrm{~min}$ before $9.5 \mathrm{~mL}$ of $8 \% \mathrm{NaOH}$ was added. The absorbance monitored at $410 \mathrm{~nm}$ was used to calculate the $\mathrm{NO}_{3}{ }^{-}$concentration with respect to the standard curve. $\mathrm{NH}_{4}{ }^{+}$was extracted and analyzed by the ninhydrin hydrate (NIN) method described by Solorzano [42]. Briefly, $1.0 \mathrm{~g}$ of tissue was ground in $10 \mathrm{~mL}$ of $10 \%$ acetic acid and then diluted to $25 \mathrm{~mL}$ with distilled water. The reaction mixture contained $2 \mathrm{~mL}$ supernatant, $3 \mathrm{~mL} \mathrm{NIN}$, and $0.1 \mathrm{~mL}$ ascorbic acid. The mixture was boiled for $15 \mathrm{~min}$ and then cooled on ice. The absorbance of the mixture measured at $580 \mathrm{~nm}$ was used to calculate the $\mathrm{NH}_{4}{ }^{+}$concentration.

\subsection{Determination of Nitrogen Metabolism Enzyme Activity and Free Amino Acids}

The NR activity in the pepper leaves was determined using the method of Gangwar and Singh [43]. The method of Jiao et al. [44] was used for the determination of glutamate synthase (GOGAT) activity. The activities of glutamine synthase (GS) and glutamate dehydrogenase (GDH) were measured as described by Shapiro and Stadtman [45] and Majerowicz et al. [46], respectively. 
Free amino acids were assayed according to Aurisano et al. [47]. Briefly, $100 \mathrm{mg}$ of dry leaves was used for the extraction of free amino acids by the addition of $\mathrm{HCl}$ to the hydrolysis tube before being vacuum infiltrated, sealed, and finally hydrolyzed at $110{ }^{\circ} \mathrm{C}$ for $24 \mathrm{~h}$. The extracts were diluted to $25 \mathrm{~mL}$ with cooled hydrolysate and then filtered. The filtrate was dissolved in deionized water and then dried by vacuum evaporation. The final dry matter dissolved in citrate buffer $(67 \mathrm{mM}, \mathrm{pH} 2.2)$ was used to determine the content of free amino acids by an amino acid analyzer (L-8900, Hitachi High-Technologies Corporation, Tokyo, Japan).

\subsection{Statistical Analyses}

All the data were subjected to one-way ANOVA using the SAS 8.1 software (SAS Institute, Inc., Cary, NC, USA). The significant differences among treatments were assayed by Duncan's multiple range test at $p<0.05$. The data were expressed as the mean \pm S.E.

\section{Results}

\subsection{Effects of Exogenous EBR on the Plant Growth and Foliar Pigment Contents of Pepper Seedlings}

The plant growth and pigment contents were significantly decreased by chilling stress compared with their respective controls. However, the foliar preapplication of EBR markedly promoted the plant growth and QI of the pepper seedlings (Figure 1 and Table 1). Moreover, when the chilling-stressed plants were pretreated with EBR, the plant height, stem diameter, fresh weight, dry weight, and $Q I$ were significantly increased by $17.3 \%, 6.1 \%, 74.7 \%, 84.6 \%$, and $63.6 \%$, respectively, compared with their controls (Table 1). Furthermore, preapplication of EBR counteracted chilling-induced decreases in chlorophyll and carotenoid contents in the leaves of the pepper seedlings (Table 2).

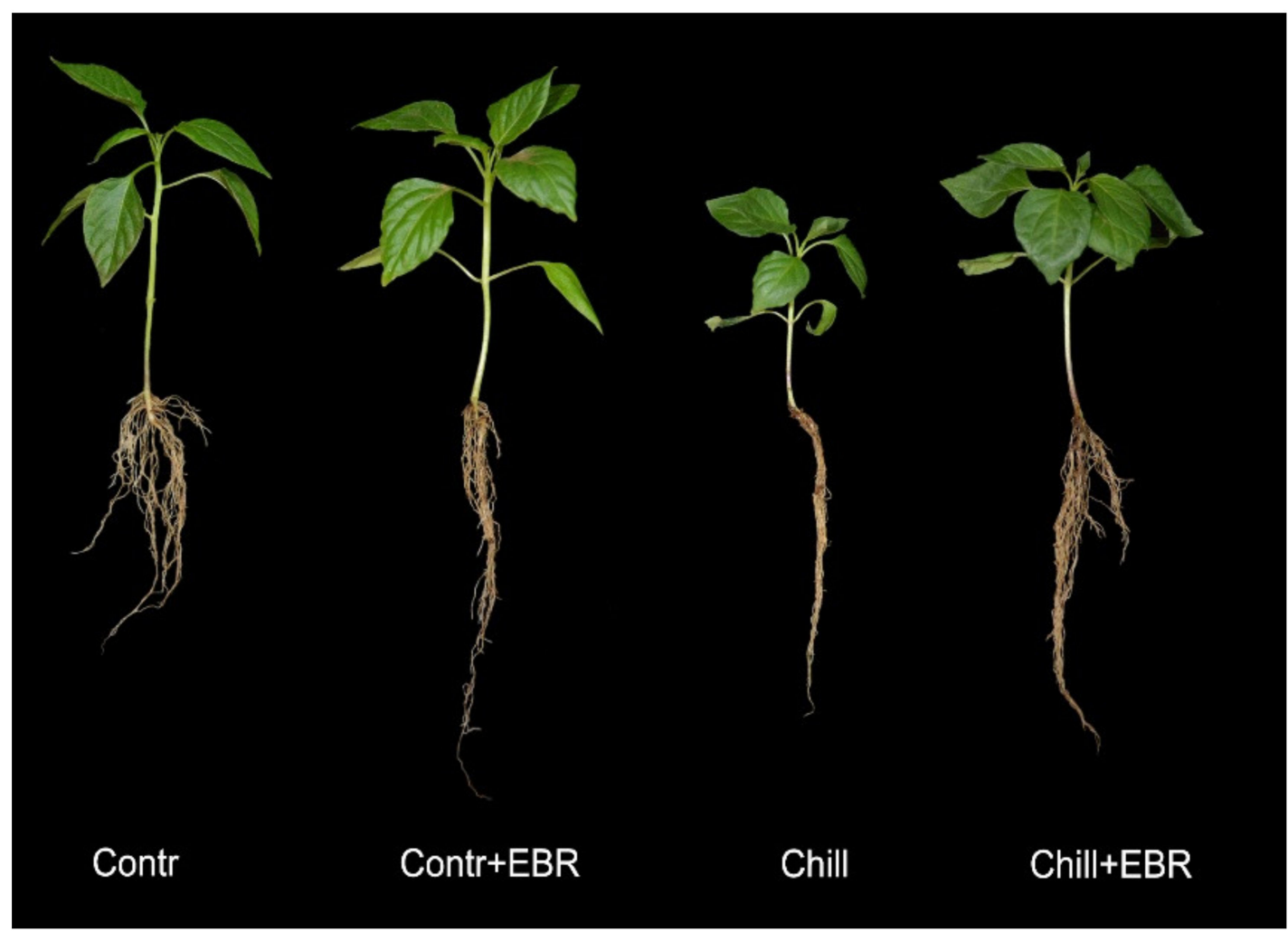

Figure 1. The phenotypes of pepper seedlings under different temperature conditions treated with or without 24-epibrassinolide (EBR). Contr, Control; Contr + EBR, Control with $0.1 \mu \mathrm{M}$ EBR; Chill, Chilling stress; Chill + EBR, Chilling stress with $0.1 \mu \mathrm{M}$ EBR. 
Table 1. The effects of exogenous 24-epibrassinolide (EBR) on the plant growth of pepper seedlings under different temperature conditions.

\begin{tabular}{cccccc}
\hline Treatment & $\begin{array}{c}\text { Plant Height } \\
(\mathbf{c m})\end{array}$ & $\begin{array}{c}\text { Stem Diameter } \\
\mathbf{( c m})\end{array}$ & $\begin{array}{c}\text { Fresh Weight } \\
(\mathbf{F W}, \mathbf{g})\end{array}$ & $\begin{array}{c}\text { Dry Weight } \\
\mathbf{( D W}, \mathbf{g})\end{array}$ & $\begin{array}{c}\text { Index of Seedling } \\
\text { Quality }(\mathbf{Q I})\end{array}$ \\
\hline Contr & $11.80 \pm 0.20 \mathrm{a}$ & $2.45 \pm 0.05 \mathrm{~b}$ & $2.07 \pm 0.13 \mathrm{a}$ & $0.22 \pm 0.01 \mathrm{a}$ & $0.045 \pm 0.004 \mathrm{~b}$ \\
Contr + EBR & $12.23 \pm 0.25 \mathrm{a}$ & $2.77 \pm 0.02 \mathrm{a}$ & $2.34 \pm 0.31 \mathrm{a}$ & $0.24 \pm 0.05 \mathrm{a}$ & $0.057 \pm 0.003 \mathrm{a}$ \\
Chill & $9.03 \pm 0.46 \mathrm{~d}$ & $2.22 \pm 0.07 \mathrm{c}$ & $0.96 \pm 0.18 \mathrm{c}$ & $0.09 \pm 0.02 \mathrm{c}$ & $0.022 \pm 0.007 \mathrm{~d}$ \\
Chill + EBR & $10.60 \pm 0.26 \mathrm{c}$ & $2.36 \pm 0.02 \mathrm{~b}$ & $1.67 \pm 0.17 \mathrm{~b}$ & $0.16 \pm 0.02 \mathrm{~d}$ & $0.036 \pm 0.002 \mathrm{c}$ \\
\hline
\end{tabular}

Data represent the mean \pm S.E. $(n=9)$. Values with different letters in the same column indicate significant difference at $p<0.05$ according to Duncan's multiply range test.

Table 2. Effect of EBR on the chlorophyll and carotenoid contents of pepper seedlings under chilling stress.

\begin{tabular}{|c|c|c|c|c|c|}
\hline Treatment & $\begin{array}{c}\text { Chl a } \\
\left(\mathrm{mg} \mathrm{g}^{-1} \mathrm{FW}\right)\end{array}$ & $\begin{array}{c}\text { Chl b } \\
\left(\mathrm{mg} \mathrm{g}^{-1} \mathrm{FW}\right)\end{array}$ & $\begin{array}{c}\mathrm{Chl} \mathrm{a+b} \\
\left(\mathrm{mg} \mathrm{g}^{-1} \mathrm{FW}\right)\end{array}$ & $\mathrm{Chl} \mathbf{a} / \mathrm{b}$ & $\begin{array}{l}\text { Carotenoids } \\
\left(\mathrm{mg} \mathrm{g}^{-1} \mathrm{FW}\right)\end{array}$ \\
\hline Contr & $1.17 \pm 0.0713 \mathrm{a}$ & $0.28 \pm 0.0406 \mathrm{ab}$ & $1.48 \pm 0.3041 \mathrm{a}$ & $4.22 \pm 0.8569 \mathrm{a}$ & $0.28 \pm 0.0180 \mathrm{ab}$ \\
\hline Contr + EBR & $1.20 \pm 0.1541 \mathrm{a}$ & $0.33 \pm 0.0224 \mathrm{a}$ & $1.50 \pm 0.0936 \mathrm{a}$ & $3.64 \pm 0.4828 \mathrm{a}$ & $0.30 \pm 0.0197 \mathrm{a}$ \\
\hline Chill & $0.82 \pm 0.0378 b$ & $0.21 \pm 0.0053 c$ & $1.05 \pm 0.0613 b$ & $3.70 \pm 0.2729 a$ & $0.22 \pm 0.0053 c$ \\
\hline Chill + EBR & $1.12 \pm 0.0343 a$ & $0.27 \pm 0.0127 \mathrm{~b}$ & $1.40 \pm 0.0499 a$ & $4.58 \pm 0.8391 \mathrm{a}$ & $0.27 \pm 0.0127 \mathrm{~b}$ \\
\hline
\end{tabular}

Data represent the mean \pm S.E. $(n=3)$. Values with different letters in the same column indicate significant difference at $p<0.05$ according to Duncan's multiply range test.

\subsection{Exogenous EBR Enhances Photosynthesis of Pepper Leaves under Chilling Stress}

Under normal temperature conditions, the values of $A_{n e t}, g_{s}$, and $T r$ under Contr + EBR were higher than those under Contr. Chilling stress led to significant decreases in those photosynthetic parameters (except $C_{\mathrm{i}}$ ). However, when chilling-stressed plants were pretreated with EBR, the values of $A_{n e t}, g_{s}$, and $\operatorname{Tr}$ were markedly increased by $66.7 \%, 53.5 \%$, and $45.7 \%$, respectively, compared with those under chilling stress (Figure 2A,B,D). Notably, exogenous EBR had little effect on the value of $\mathrm{C}_{\mathrm{i}}$, as shown by the comparable values of plants between EBR-treated and non-EBR-treated plants under both normal temperatures and chilling stress conditions (Figure 2C).
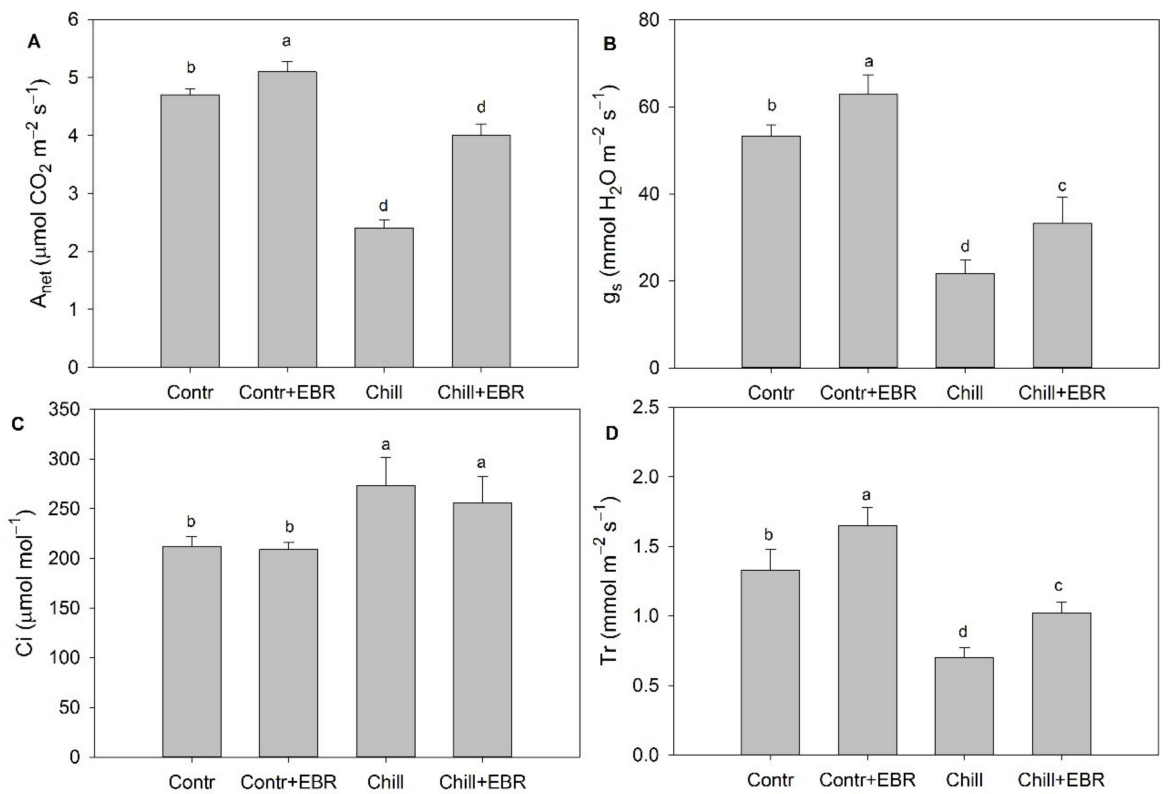

Figure 2. Effect of exogenous EBR on gas exchange parameters of pepper seedlings. (A) The net rate of photosynthesis; (B) stomatal conductance $\left(\mathrm{g}_{\mathrm{s}}\right)$; (C) the concentration of intercellular $\mathrm{CO}_{2}\left(\mathrm{C}_{\mathrm{i}}\right)$; (D) transpiration rate (Tr). Contr, Control; Contr + EBR, Control with $0.1 \mu \mathrm{M}$ EBR; Chill, Chilling stress; Chill + EBR, Chilling stress with $0.1 \mu \mathrm{M}$ EBR. Values are the means with standard errors, shown by the vertical bars $(n=3)$. Different letters indicate significant differences among treatments at $p<0.05$. 


\subsection{Exogenous EBR Maintains High Photosynthesis Capability and Photosystem Balance in Pepper Leaves under Chilling Stress}

Foliar spray of EBR significantly affected $\mathrm{A}_{\text {net }}$ under different light intensities and intercellular carbon dioxides. The enhanced effects of EBR on $\mathrm{A}_{\text {net }}$ became increasingly greater with the increase of light intensity and intercellular carbon dioxide (Figure 3). Under normal growth conditions, foliar spraying of EBR had little effect on the chlorophyll fluorescence parameters, as shown by the comparable values of $\mathrm{F}_{\mathrm{v}} / \mathrm{F}_{\mathrm{m}}, \Phi_{\mathrm{PSII}}, \mathrm{qP}$, and $\mathrm{F}_{\mathrm{v}}{ }^{\prime} / \mathrm{F}_{\mathrm{m}}$ ' between Contr and Contr + EBR. However, pretreated with EBR significantly increased these fitting parameters of $A_{\max }$ and $V_{\max }$. Under chilling stress conditions, the values of $\mathrm{F}_{\mathrm{v}} / \mathrm{F}_{\mathrm{m}}, \Phi_{\mathrm{PSII}}, \mathrm{qP}, \mathrm{F}_{\mathrm{v}}{ }^{\prime} / \mathrm{F}_{\mathrm{m}}{ }^{\prime}$, and these fitting parameters (except $\mathrm{R}_{\mathrm{d}}$ ) under Chill $+\mathrm{EBR}$ were markedly higher than those under Chill (Table 3). Furthermore, the values of E and $\beta / \alpha-1$ under Chill were higher than those under Contr, indicating that chilling stress led to excessive energy accumulation and imbalance between PSII and PSI in the leaves of the pepper seedlings. However, pretreatment with EBR alleviated the chilling-stress-induced accumulation of excessive energy and imbalance of photosystems, as shown by the lower E and $\beta / \alpha-1$ under Chill + EBR compared with those under Chill (Table 3). These results indicate that the preapplication of EBR could enhance the chilling tolerance of pepper seedlings in terms of the photosynthetic activity.
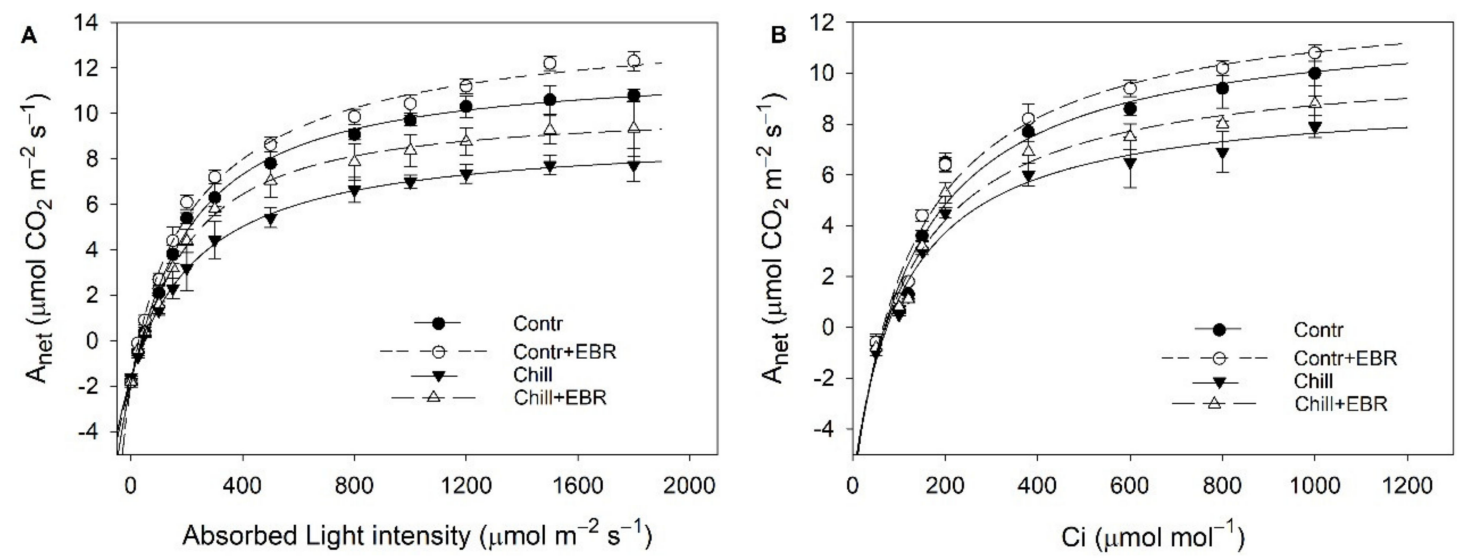

Figure 3. Effects of exogenous EBR on photosynthetic response curves of pepper seedlings under chilling stress. (A) The response of the net rate of photosynthesis $\left(\mathrm{A}_{\text {net }}\right)$ to light irradiance; (B) the response of $A_{\text {net }}$ to intercellular carbon dioxide $\left(C_{i}\right)$. Contr, Control; Contr + EBR, Control with $0.1 \mu \mathrm{M}$ EBR; Chill, Chilling stress; Chill + EBR, Chilling stress with $0.1 \mu \mathrm{M}$ EBR. Values are the means with standard errors, shown by the vertical bars ( $n=3$ or 4$)$.

Table 3. The effects of exogenous EBR on different chlorophyll fluorescence and energy distribution parameters measured or calculated for pepper leaves under chilling stress.

\begin{tabular}{ccccc}
\hline \multicolumn{1}{c}{ Contr } & Contr + EBR & Chill & Chill + EBR \\
\hline \multicolumn{5}{c}{ Measured parameters } \\
\hline $\mathrm{F}_{\mathrm{V}} / \mathrm{F}_{\mathrm{m}}$ & $0.84 \pm 0.021 \mathrm{a}$ & $0.85 \pm 0.017 \mathrm{a}$ & $0.79 \pm 0.010 \mathrm{c}$ & $0.81 \pm 0.006 \mathrm{~b}$ \\
$\Phi_{\mathrm{PSII}}$ & $0.74 \pm 0.009 \mathrm{a}$ & $0.74 \pm 0.008 \mathrm{a}$ & $0.58 \pm 0.005 \mathrm{c}$ & $0.66 \pm 0.004 \mathrm{~b}$ \\
$\mathrm{q}$ & $0.97 \pm 0.002 \mathrm{a}$ & $0.97 \pm 0.009 \mathrm{a}$ & $0.83 \pm 0.013 \mathrm{c}$ & $0.88 \pm 0.014 \mathrm{~b}$ \\
$\mathrm{~F}_{\mathrm{v}}{ }^{\prime} / \mathrm{F}_{\mathrm{m}}{ }^{\prime}$ & $0.76 \pm 0.009 \mathrm{a}$ & $0.76 \pm 0.003 \mathrm{a}$ & $0.70 \pm 0.008 \mathrm{c}$ & $0.73 \pm 0.006 \mathrm{~b}$ \\
$E$ & $0.021 \pm 0.001 \mathrm{c}$ & $0.022 \pm 0.007 \mathrm{c}$ & $0.12 \pm 0.010 \mathrm{a}$ & $0.092 \pm 0.012 \mathrm{~b}$ \\
$\beta / \alpha-1$ & $0.028 \pm 0.002 \mathrm{c}$ & $0.029 \pm 0.009 \mathrm{c}$ & $0.20 \pm 0.019 \mathrm{a}$ & $0.14 \pm 0.018 \mathrm{~b}$ \\
\hline \multicolumn{5}{c}{ Fitting parameters } \\
\hline $\mathrm{A}_{\max }$ & $14.0 \pm 0.25 \mathrm{~b}$ & $15.7 \pm 0.37 \mathrm{a}$ & $10.6 \pm 0.15 \mathrm{~d}$ & $11.9 \pm 0.10 \mathrm{c}$ \\
$\mathrm{R}_{\mathrm{d}}$ & $1.95 \pm 12.9 \mathrm{ab}$ & $1.98 \pm 4.65 \mathrm{a}$ & $1.38 \pm 6.22 \mathrm{c}$ & $1.60 \pm 0.67 \mathrm{bc}$ \\
$\mathrm{J}_{\max }$ & $82.3 \pm 0.83 \mathrm{a}$ & $85.1 \pm 1.33 \mathrm{a}$ & $71.1 \pm 3.42 \mathrm{c}$ & $76.2 \pm 1.02 \mathrm{~b}$ \\
$\mathrm{~V}_{\max }$ & $47.5 \pm 0.87 \mathrm{~b}$ & $51.4 \pm 0.87 \mathrm{a}$ & $38.8 \pm 1.32 \mathrm{~d}$ & $44.3 \pm 0.76 \mathrm{c}$ \\
\hline
\end{tabular}

Data represent the mean \pm S.E. $(n=3)$. Values with different letters in the same row indicate significant difference at $p<0.05$ according to Duncan's multiply range test. 
3.4. Exogenous EBR Reduces ROS Accumulation and Mitigates Lipid Peroxidation in Pepper Leaves under Chilling Stress

Compared with normal growth conditions, chilling stress led to significant increases in the content of $\mathrm{H}_{2} \mathrm{O}_{2}$, the rate of $\mathrm{O}_{2}{ }^{-\cdot}$, and the MDA content by $134.6 \%, 79.6 \%$, and $32.1 \%$, respectively. Exogenous EBR alleviated the chilling-stress-induced accumulation of ROS and membrane lipid peroxidation, with the content of $\mathrm{H}_{2} \mathrm{O}_{2}$, the rate of $\mathrm{O}_{2}{ }^{-\cdot}$ and the MDA content under Chill + EBR decreasing by $24.3 \%$, $20.0 \%$, and $13.9 \%$, respectively. However, EBR application had little effect on ROS accumulation and lipid peroxidation under normal growth conditions (Table 4). The positive effects of EBR on alleviating chilling-induced injury were further verified by histochemical localization staining of $\mathrm{H}_{2} \mathrm{O}_{2}, \mathrm{O}_{2}{ }^{-\cdot}$ and lipid peroxidation in leaves of pepper seedlings (Figure 4A-C).

Table 4. Effect of exogenous EBR on reactive oxygen species (ROS) and membrane lipid peroxidation of pepper seedlings.

\begin{tabular}{|c|c|c|c|}
\hline Treatment. & $\mathrm{H}_{2} \mathrm{O}_{2}\left(\mu \mathrm{mol} \mathrm{g}^{-1}, \mathrm{FW}\right)$ & $\mathrm{O}_{2}^{-\cdot}\left(\mu \mathrm{mol} \min ^{-1} \mathrm{~g}^{-1}, \mathrm{FW}\right)$ & MDA $\left(\mu \mathrm{mol} \mathrm{g}{ }^{-1}, F W\right)$ \\
\hline Contr & $0.34 \pm 0.017 c$ & $0.22 \pm 0.011 \mathrm{c}$ & $0.32 \pm 0.009 c$ \\
\hline Contr + EBR & $0.33 \pm 0.021 c$ & $0.21 \pm 0.025 c$ & $0.32 \pm 0.008 c$ \\
\hline Chill & $0.78 \pm 0.025 a$ & $0.40 \pm 0.027 \mathrm{a}$ & $0.43 \pm 0.011 \mathrm{a}$ \\
\hline Chill + EBR & $0.59 \pm 0.010 b$ & $0.31 \pm 0.017 b$ & $0.36 \pm 0.005 b$ \\
\hline
\end{tabular}

Data represent the mean \pm S.E. $(n=3)$. Values with different letters in the same column indicate significant difference at $p<0.05$ according to Duncan's multiply range test.
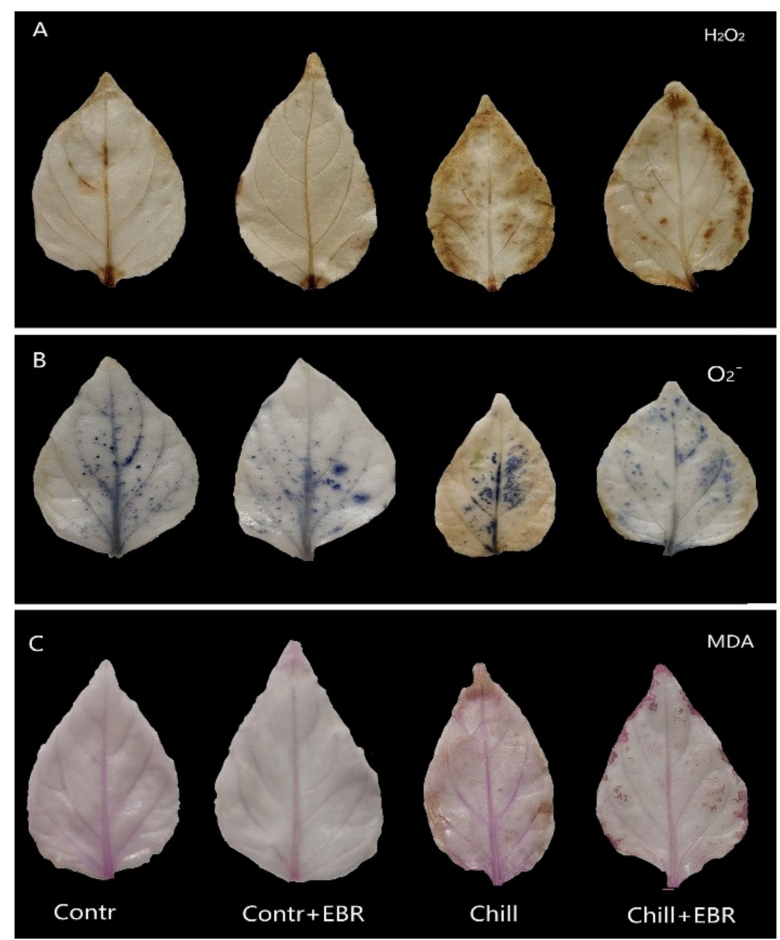

Figure 4. Exogenous EBR effects on levels of reactive oxygen species (ROS) and equivalents of malondialdehyde (MDA). (A) Histochemical localization of $\mathrm{H}_{2} \mathrm{O}_{2}$ by DAB staining after 7 days of chilling treatment; (B) histochemical localization of $\mathrm{O}_{2}^{-\cdot}$ by NBT staining; (C) histochemical localization of MDA by Schiff's reagent staining. Contr, Control; Contr + EBR, Control with $0.1 \mu \mathrm{M}$ EBR; Chill, Chilling stress; Chill + EBR, Chilling stress with $0.1 \mu \mathrm{M}$ EBR.

3.5. Exogenous EBR Promotes Nitrogen Metabolism via Increasing the Activities of NR, GS, GOGAT, and GDH in the Leaves of Pepper Seedlings

Nitrogen assimilation in pepper seedlings was significantly affected by exogenous EBR (Figure 5). Under normal growth conditions, foliar pretreatment with EBR enhanced $\mathrm{NO}_{3}{ }^{-}$accumulation but 
showed little effect on $\mathrm{NH}_{4}{ }^{+}$content. Similarly, exogenous EBR also increased the $\mathrm{NO}_{3}{ }^{-}$content in pepper leaves under chilling stress but led to a significant decrease in the content of $\mathrm{NH}_{4}{ }^{+}$, as shown by the higher $\mathrm{NO}_{3}{ }^{-}$and concomitantly lower $\mathrm{NH}_{4}{ }^{+}$under Chill + EBR than those under Chill (Figure 5A,B). Pretreatment with EBR showed little effects on the activities of NR, GS, GOGAT, and GDH in pepper leaves under normal growth conditions. However, exogenous EBR alleviated the negative effect of chilling stress on the activities of those nitrogen enzymes, with the activities of NR, GS, GOGAT, and GDH under Chill + EBR increasing by $21.3 \%, 44.6 \%, 43.4 \%$, and $58.3 \%$, respectively, compared with those under Chill (Figure 6).
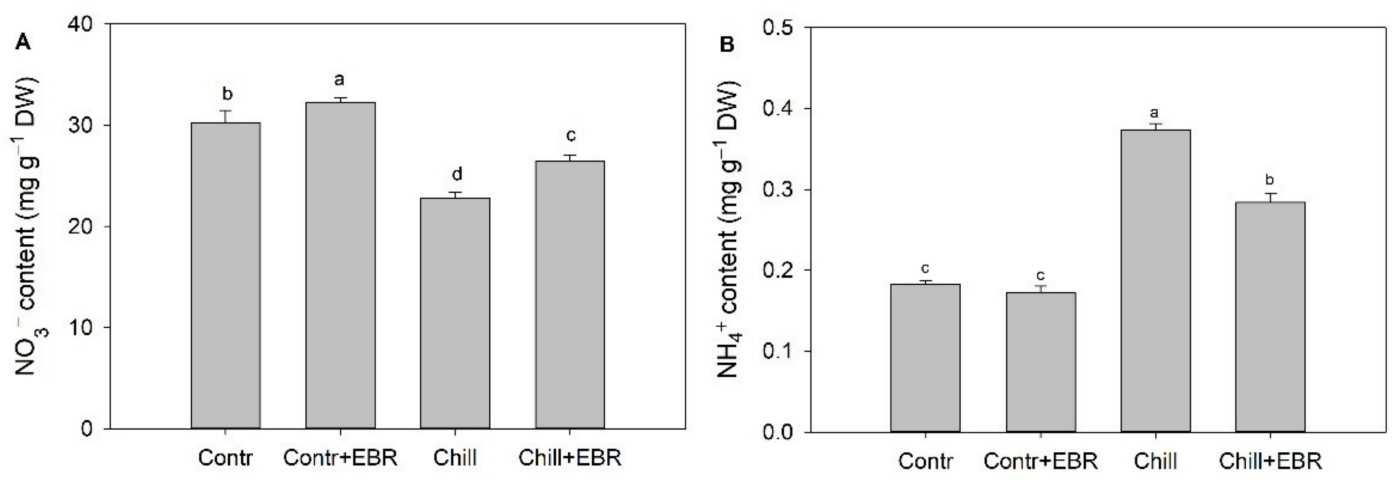

Figure 5. Effect of exogenous EBR on the content of nitrate (A) and ammonium nitrogen (B) in pepper seedlings. Contr, Control; Contr + EBR, Control with $0.1 \mu \mathrm{M}$ EBR; Chill, Chilling stress; Chill + EBR, Chilling stress with $0.1 \mu \mathrm{M}$ EBR. Values are the means with standard errors, shown by the vertical bars $(n=3)$. Different letters indicate significant differences among treatments at $p<0.05$.
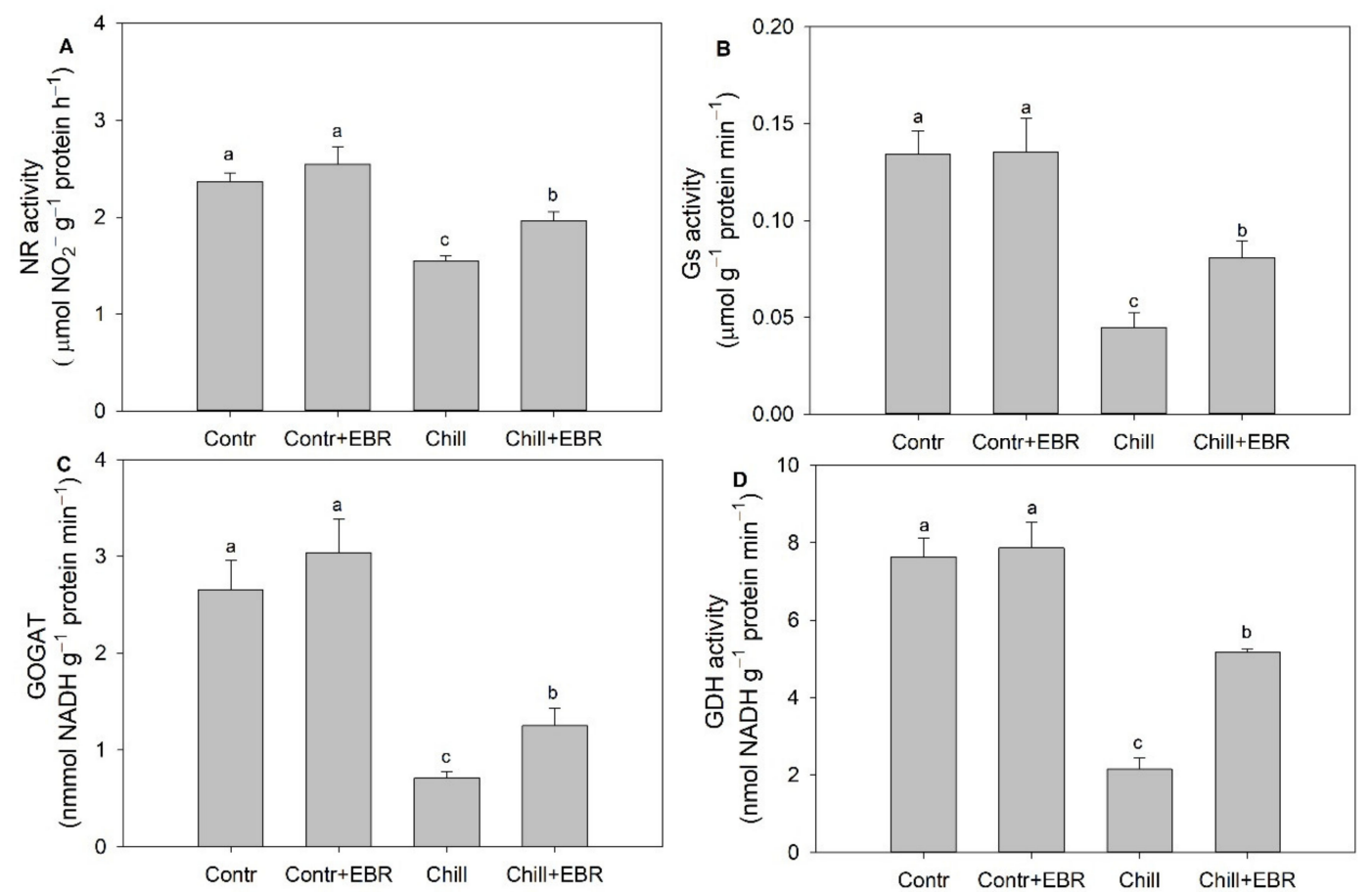

Figure 6. Effect of exogenous EBR on the enzyme activities of nitrogen metabolism in pepper seedlings under chilling stress. (A) Nitrate reductase (NR) activity; (B) glutamine synthase (GS) activity; (C) glutamate synthase (GOGAT) activity; (D) glutamate dehydrogenase (GDH) activity. Contr, Control; Contr + EBR, Control with $0.1 \mu \mathrm{M}$ EBR; Chill, Chilling stress; Chill + EBR, Chilling stress with $0.1 \mu \mathrm{M}$ EBR. Values are the means with standard errors, shown by the vertical bars $(n=3)$. Different letters indicate significant differences among treatments at $p<0.05$. 
3.6. Exogenous EBR Results in an Increase in Amino Acid Accumulation in the Leaves of Pepper Seedlings under Chilling Stress

The accumulation of free amino acids was significantly affected by pretreatment with EBR (Figure 7). Under normal growth conditions, the values of cysteine, lysine, threonine, tyrosine, valine, and total free amino acids under Contr + EBR were higher than those under Contr. Under chilling stress, exogenous EBR significantly improved the content of arginine, aspartic acid, glutamic acid, glycine, and proline in the pepper leaves, with the values increasing by $10.2 \%, 4.6 \%, 8.7 \%, 11.9 \%$, and $13.4 \%$, respectively, but led to the contents of alanine, lysine, threonine, tyrosine, and valine decreasing by $10.6 \%, 28.7 \%, 16.5 \%, 21.4 \%$, and $12.3 \%$, respectively (Figure. 7 ).

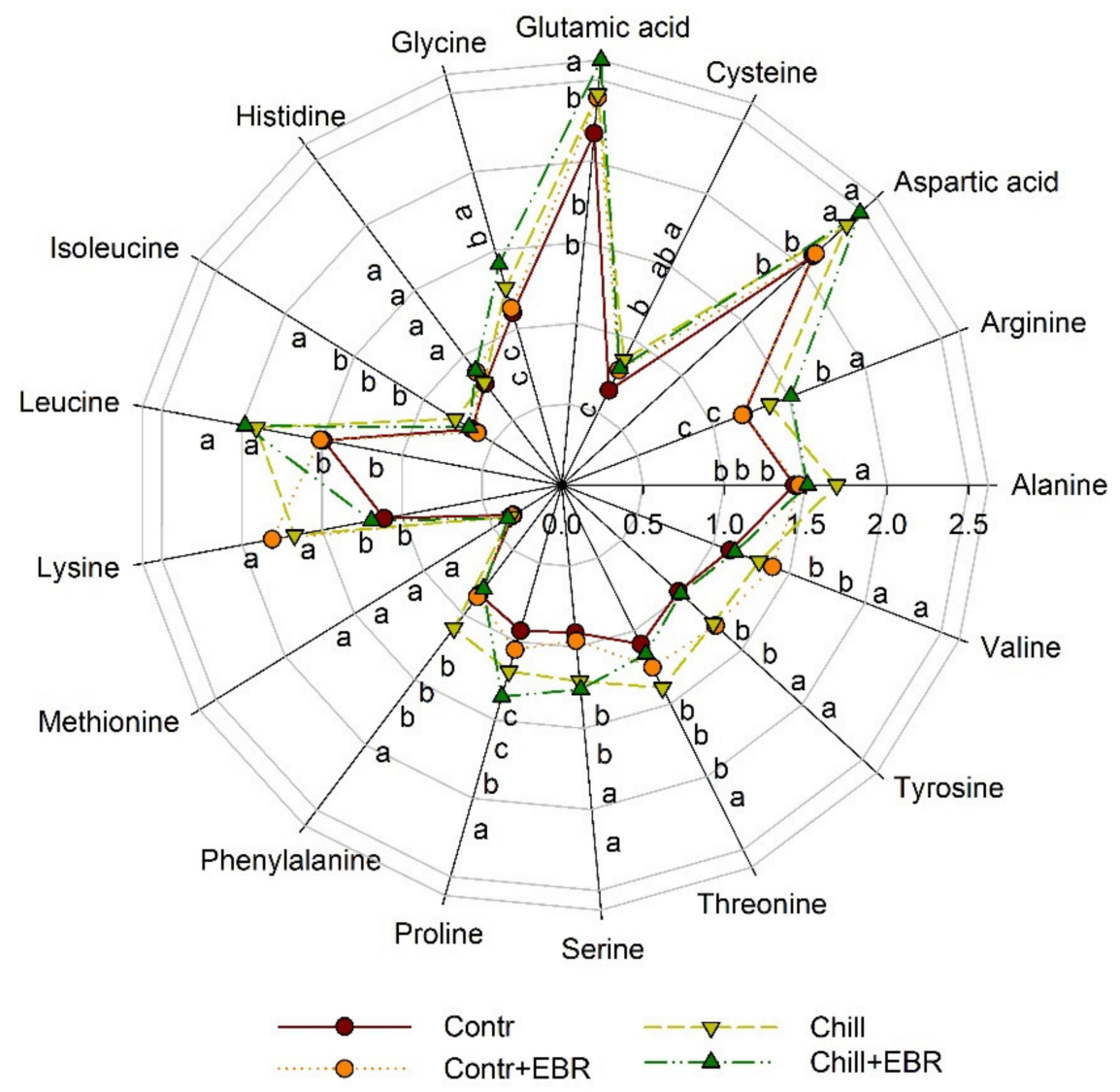

Figure 7. Effect of exogenous EBR on the amino acid content of pepper seedlings under low temperature stress (\%DW). Contr, Control; Contr + EBR, Control with $0.1 \mu \mathrm{M} \mathrm{EBR;} \mathrm{Chill,} \mathrm{Chilling} \mathrm{stress;} \mathrm{Chill} \mathrm{+}$ EBR, Chilling stress with $0.1 \mu \mathrm{M}$ EBR. Values are the means with standard errors, shown by the vertical bars $(n=3)$. Different letters indicate significant differences among treatments at $p<0.05$.

\section{Discussion}

Brassinosteroids (BRs), as polyhydroxylated steroidal plant hormones, are involved in plant physiological processes [14,48]. This present study extends our previous work on EBR in the regulation of chilling tolerance from hormone metabolism, calcium signaling transduction, and cellular redox homeostasis [19,49]. Here, we have demonstrated the positive role of EBR in enhancing plant growth and development through maintaining higher photosynthetic capability and nitrogen metabolism (Figure 8). However, these positive effects were more significant under chilling stress than under normal growth conditions. Similar results were reported in tomatoes grown under different temperature conditions [50]. This may lie in the fact that EBR-induced plant growth and development responses are strictly concentration dependent and the optimal concentration for improving growth and nitrogen 
metabolism vary depending on the plant species, developmental stages, and growth conditions as well [51]. However, the in-depth mechanisms of BRs-induced stress tolerance still remain largely unknown.

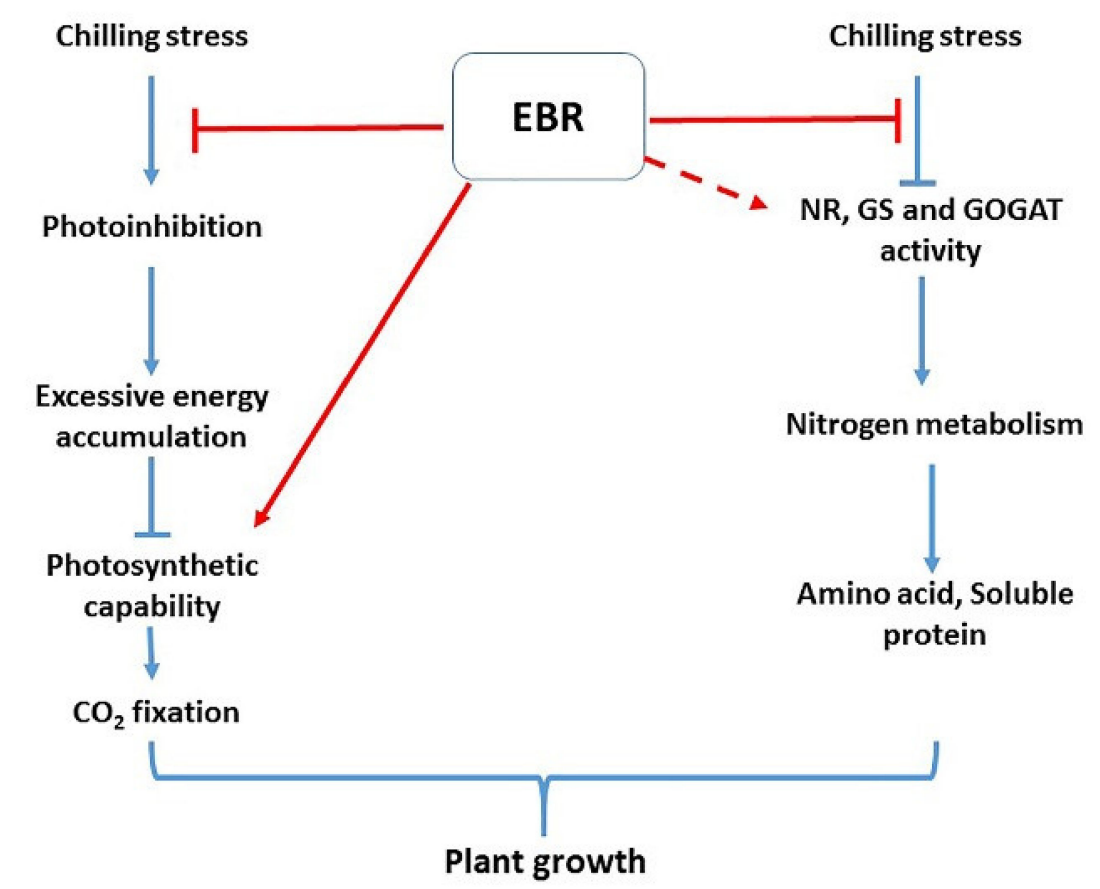

Figure 8. Schematic representation of exogenous EBR effects on photosynthetic capability and nitrogen metabolism in pepper seedlings under chilling stress.

In nature, the first reaction of plants to biotic or/and abiotic stress is a decrease in photosynthesis, followed by plant growth retardation and loss of yield [52]. In the present study, exogenous application of EBR alleviated chilling-stress-induced decreases in plant growth (Table 1). This phenomenon can be explained by the higher photosynthetic capability after EBR application, as shown by the higher photosynthetic parameters (e.g., $A_{\text {net }}, A_{\max }$, and $\mathrm{J}_{\max }$ ) under EBR treatments (Table 2). Similar results were also reported in BR-treated tomato seedlings [6]. In plant leaves, $\mathrm{F}_{\mathrm{v}} / \mathrm{F}_{\mathrm{m}}, \mathrm{qP}$, and $\mathrm{F}_{\mathrm{v}}{ }^{\prime} / \mathrm{F}_{\mathrm{m}}{ }^{\prime}$ are important fluorescence parameters that reflect the status of photochemical quenching [53]. $F_{v} / F_{m}$ is also an indicator of photoinhibition, and the level of this parameter reflects the rate of damage to PSII under stress conditions [32,34]. Under chilling stress conditions, the significantly higher $F_{v} / F_{m}$, $\mathrm{qP}$, and $\mathrm{F}_{\mathrm{v}}{ }^{\prime} / \mathrm{F}_{\mathrm{m}}{ }^{\prime}$ and concomitantly lower $\mathrm{E}$ and $\beta / \alpha-1$ in EBR-pretreated leaves (Table 3 ) indicate that EBR mitigated the chilling-stress-induced inactivation of and damage to the photosynthetic apparatus $[35,54]$. Together with the higher-fitted photosynthetic parameters observed under Chill + EBR (Table 3), these results confirmed the positive role of EBR in protecting photosystem stability, thereby alleviating the chilling-stress-induced decrease in photosynthetic capability [18]. In this study, foliar preapplication of EBR had little effect on $C_{i}$. Similar results were also reported in melon under heat stress [55]. The increase or decrease in $g_{s}$ of pepper seedlings pretreated with EBR under chilling or nonchilling conditions could not relate to the changes in $C_{i}$, indicating that $g_{s}$ was not the sole factor for EBR-induced photosynthetic changes under different temperature conditions. Under stress conditions, the reduced $\mathrm{A}_{\text {net }}$ can result from stomata or nonstomata limitations in higher plants [56]. The stomatal conductance $\left(g_{s}\right)$ and mesophyll conductance are two major constraints of $A_{\text {net }}$ [57], and there are revealing tradeoffs between mesophyll and stomatal conductance in response of different stress [58]. Thus, the changes in $\mathrm{A}_{\text {net }}$ in the pepper seedlings under chilling stress are likely due to the decrease in photosynthetic activity in mesophyll cells rather than reflecting a change in stomatal behavior. This view could be further supported by the study of wheat treated with/without EBR under salt stress [17]. 
Under stress conditions, the reduction in photosynthetic capability caused by the decrease in the process of photochemical quenching will lead to excessive accumulation of absorbed energy in PSII, which will be used to generate ROS in plant leaves [59]. The light intensity and light spectra play inevitable roles in chilling-induced photoinhibition, and high light intensity aggravates the negative effects of chilling stress on plant growth and development [18]. In off-season cultivation facilities, the chilling stress is always accompanied by low light conditions. Thus, when performing chilling stress treatment, we reduced the light intensity to minimize the potentially negative effects of light intensity on the photosystem under chilling stress. Therefore, the results of this study could more realistically reveal the function of EBR in regulating plant chilling tolerance in protected facilities during cold season. The results of this study confirmed the positive role of EBR in enhancing the plant tolerance to chilling stress, as assayed by the lower content of MDA and ROS under Chill + EBR (Table 4 and Figure 4).

Exogenous EBR has been shown to be involved in nitrogen metabolism, which plays a positive role in nitrogen starvation tolerance in tomatoes [60]. In the present study, the exogenous EBR-induced increases in the activities of nitrogen metabolism enzymes were observed only under chilling stress. This is consistent with results of EBR on nitrogen metabolism in chill-stressed tomato seedlings under [50] and in hypoxia-stressed cucumber seedlings [61]. In addition, exogenous EBR increased $\mathrm{NR}$ activity and photosynthesis in plant leaves under chilling stress but led to $\mathrm{NO}_{3}{ }^{-}$accumulation in plant leaves. Similar results of EBR on nitrate metabolism were also reported by He et al. [41]. These results indicate that EBR not only plays a positive role in enhancing $\mathrm{NO}_{3}{ }^{-}$assimilation but may also be involved in regulating $\mathrm{NO}_{3}{ }^{-}$absorption and transport in plants. $\mathrm{The}^{-} \mathrm{NH}_{4}{ }^{+}$generated from $\mathrm{NO}_{3}{ }^{-}$assimilation, along with absorption from the soil, will be proportionately assimilated by the GS/GOGAT pathway and GDH pathway [62,63]. It was speculated that GDH plays a unique physiological role in the release of large amounts of ammonium in plants under abiotic stress [36,62]. In this study, foliar spraying of EBR reduced the potential toxicity induced by excess accumulation of $\mathrm{NH}_{4}{ }^{+}$via improving the activity of nitrogen-ammonia anabolic enzymes (Figure 6), thereby increasing the plant chilling tolerance.

The assimilation of nitrogen is directly responsible for biomass accumulation and crop yield [64]. Glutamine and glutamic acid produced via the GS/GOGAT pathway are the preconditions for the synthesis of nitrogenous organics such as amino acids, nucleic acids, chlorophyll, and polyamines in plants. The application of EBR increased the content of some soluble amino acids (Figure 7). Among soluble amino acids, proline was regarded not only as a stabilizer of plant membranes under unfavorable environmental conditions, but also as a free radical scavenger to enhance the anti-stress ability of plants [65]. In the present study, the positive effects of EBR on mitigating the chilling-induced negative effects on pepper seedlings could partly be attributed to the increase in free proline content after EBR application. This view was supported by the study of Vidya Vardhini and Seeta Ram Rao [66], who found that EBR enhances resistance to osmotic stress via increasing the proline levels.

Taken together, exogenous application of EBR enhanced the chilling tolerance of pepper seedlings by maintaining higher photosynthetic capability and enhancing nitrogen metabolism. In addition to enhancing $\mathrm{NR}$ activity, the accumulation of $\mathrm{NO}_{3}{ }^{-}$in pepper seedlings after EBR application suggests that EBR may participate in the regulation of $\mathrm{NO}_{3}{ }^{-}$absorption and translation in plants. Therefore, future studies concerning the analysis of genetics and metabolomics will shed light on the regulation of EBR on plant growth and development.

\section{Conclusions}

Our study showed that foliar spraying with $0.1 \mu \mathrm{M}$ EBR alleviated the inhibition of plant growth under chilling stress by maintaining higher photosynthesis and promoting nitrogen metabolism. In addition, EBR alleviated the membrane lipid peroxide caused by reactive oxygen species $\left(\mathrm{O}_{2}{ }^{-\cdot}\right.$ and $\mathrm{H}_{2} \mathrm{O}_{2}$ ) under chilling stress. The result of this study paves the way toward improved plant yield under low temperatures via the application of EBR. In the future, transcriptomic and metabolomic analyses 
will provide more information regarding how EBR regulates plant growth and development under low temperature stress.

Supplementary Materials: The following are available online at http://www.mdpi.com/2073-4395/9/12/839/s1, Table S1: The details of treatments used in this study.

Author Contributions: Z.B. and J.L. conceived the original research plan and designed the experiment. P.Y. and Y.W. performed the experimenta and data collection. J.L, P.Y and Y.W prepared the manuscript. Z.B reviewed and edited the manuscript.

Funding: This research was funded by National Natural Science Foundation of China (grant number: 31760592), Scientific Research Fund Project Yunnan Provincial Educational Department(grant number: 2017ZZX119) and Nottingham Trent University QR Fund (grant number: 01 ARE RA926).

Acknowledgments: We thank Caroline Hulland and Harley Kemp for language editing and suggestion on preparation of this manuscript.

Conflicts of Interest: The authors declaer that they have on interest conflicts.

\section{References}

1. Zhang, Y.; Wang, P.; Wang, L.; Sun, G.; Zhao, J.; Zhang, H.; Du, N. The influence of facility agriculture production on phthalate esters distribution in black soils of northeast China. China. Sci. Total Environ. 2015, 506, 118-125. [CrossRef] [PubMed]

2. Xie, J.; Yu, J.; Chen, B.; Feng, Z.; Li, J.; Zhao, C.; Lyu, J.; Hu, L.; Gan, Y.; Siddique, K.H. Facility cultivation systems “设施农业”: A Chinese model for the planet. In Advances in Agronomy; Elsevier: Amsterdam, The Netherlands, 2017; Volume 145, pp. 1-42.

3. Dhankher, O.P.; Foyer, C.H. Climate resilient crops for improving global food security and safety. Plant Cell Environ. 2018, 41, 877-884. [CrossRef] [PubMed]

4. Bilska, A.; Sowiński, P. Closure of plasmodesmata in maize (Zea mays) at low temperature: A new mechanism for inhibition of photosynthesis. Ann. Bot. 2010, 106, 675-686. [CrossRef] [PubMed]

5. Airaki, M.; Leterrier, M.; Mateos, R.M.; Valderrama, R.; Chaki, M.; Barroso, J.B.; Del Rio, L.A.; Palma, J.M.; Corpas, F.J. Metabolism of reactive oxygen species and reactive nitrogen species in pepper (Capsicum annuum L.) plants under low temperature stress. Plant Cell Environ. 2012, 35, 281-295. [CrossRef]

6. Shu, S.; Tang, Y.; Yuan, Y.; Sun, J.; Zhong, M.; Guo, S. The role of 24-epibrassinolide in the regulation of photosynthetic characteristics and nitrogen metabolism of tomato seedlings under a combined low temperature and weak light stress. Plant Physiol. Biochem. 2016, 107, 344-353. [CrossRef]

7. Khripach, V.; Zhabinskii, V.; de Groot, A. Twenty years of brassinosteroids: Steroidal plant hormones warrant better crops for the XXI century. Ann. Bot. 2000, 86, 441-447. [CrossRef]

8. Beevers, L.; Hageman, R. Nitrate reduction in higher plants. Annu. Rev. Plant Physiol. 1969, 20, 495-522. [CrossRef]

9. Giagnoni, L.; Pastorelli, R.; Mocali, S.; Arenella, M.; Nannipieri, P.; Renella, G. Availability of different nitrogen forms changes the microbial communities and enzyme activities in the rhizosphere of maize lines with different nitrogen use efficiency. Appl. Soil Ecol. 2016, 98, 30-38. [CrossRef]

10. Chow, F.; Pedersén, M.; Oliveira, M.C. Modulation of nitrate reductase activity by photosynthetic electron transport chain and nitric oxide balance in the red macroalga Gracilaria chilensis (Gracilariales, Rhodophyta). J. Appl. Phycol. 2013, 25, 1847-1853. [CrossRef]

11. Suzuki, N.; Miller, G.; Morales, J.; Shulaev, V.; Torres, M.A.; Mittler, R. Respiratory burst oxidases: The engines of ROS signaling. Curr. Opin. Plant Biol. 2011, 14, 691-699. [CrossRef]

12. Gapper, C.; Dolan, L. Control of plant development by reactive oxygen species. Plant Physiol. 2006, 141, 341-345. [CrossRef] [PubMed]

13. Gouia, H.; Suzuki, A.; Brulfert, J.; Ghorbal, M.H. Effects of cadmium on the coordination of nitrogen and carbon metabolism in bean seedlings. J. Plant Physiol. 2003, 160, 367-376. [CrossRef] [PubMed]

14. Khana, T.A.; Yusufb, M.; Ahmadc, A.; Zoobia, B.; Saeede, T.; Fariduddinf, Q.; Hayatf, S.; Mocka, H.; Wu, T.Q. Proteomic and physiological assessment of stress sensitive and tolerant variety of tomato treated with brassinosteroids and hydrogen peroxide under low-temperature stress. Food Chem. 2019, 289, 500-511. [CrossRef] [PubMed] 
15. Yu, J.Q.; Huang, L.F.; Hu, W.H.; Zhou, Y.H.; Mao, W.H.; Ye, S.F.; Nogués, S. A role for brassinosteroids in the regulation of photosynthesis in Cucumis sativus. J. Exp. Bot. 2004, 55, 1135-1143. [CrossRef] [PubMed]

16. Hu, W.H.; Yan, X.H.; Xiao, Y.A.; Zeng, J.J.; Qi, H.J.; Ogweno, J.O. 24-Epibrassinosteroid alleviate drought-induced inhibition of photosynthesis in Capsicum annuum. Sci. Hortic. 2013, 150, $232-237$. [CrossRef]

17. Ali, Q.; Ashraf, M. Modulation of growth, photosynthetic capacity and water relations in salt stressed wheat plants by exogenously applied 24-epibrassinolide. Plant Growth Regul. 2008, 56, 107-116. [CrossRef]

18. Fang, P.; Yan, M.; Chi, C.; Wang, M.; Zhou, Y.; Zhou, J.; Shi, K.; Xia, X.; Foyer, C.H.; Yu, J. Brassinosteroids act as a positive regulator of photoprotection in response to chilling stress. Plant Physiol. 2019, 180, 2061-2076. [CrossRef]

19. Li, J.; Yang, P.; Gan, Y.T.; Yu, J.H.; Xie, J.M. Brassinosteroid alleviates chilling-induced oxidative stress in pepper by enhancing antioxidation systems and maintenance of photosystem II. Acta Physiol. Plant. 2015, 37, 222. [CrossRef]

20. Liu, Y.; Jiang, H.; Zhao, Z.; An, L. Abscisic acid is involved in brassinosteroids-induced chilling tolerance in the suspension cultured cells from Chorispora bungeana. J. Plant Physiol. 2011, 168, 853-862. [CrossRef]

21. Liu, Y.; Zhao, Z.; Si, J.; Di, C.; Han, J.; An, L. Brassinosteroids alleviate chilling-induced oxidative damage by enhancing antioxidant defense system in suspension cultured cells of Chorispora bungeana. Plant Growth Regul. 2009, 59, 207-214. [CrossRef]

22. Chen, X.B.; Yao, Q.F.; Gao, X.H.; Jiang, C.F.; Harberd Nicholas, P.; Fu, X.D. Shoot-to-root mobile transcription factor HY5 coordinates plant carbon and nitrogen acquisition. Curr. Biol. 2016, 26, 640-646. [CrossRef]

23. Li, J.; Yang, P.; Xie, J.; Yu, J. Effects of 24-epibrassinolide on growth and antioxidant enzymes system in pepper roots under chilling stress. J. Nucl. Agric. Sci. 2015, 29, 1001-1008.

24. Hu, W.; Wu, Y.; Zeng, J.; He, L.; Zeng, Q. Chill-induced inhibition of photosynthesis was alleviated by 24-epibrassinolide pretreatment in cucumber during chilling and subsequent recovery. Photosynthetica 2010, 48, 537-544. [CrossRef]

25. Dickson, A.; Leaf, A.L.; Hosner, J.F. Quality appraisal of white spruce and white pine seedling stock in nurseries. For. Chron. 1960, 36, 10-13. [CrossRef]

26. Thornley, J.H. Mathematical Models in Plant Physiology; Academic Press (Inc.) Ltd.: London, UK, 1976.

27. Trouwborst, G.; Hogewoning, S.W.; Harbinson, J.; van Ieperen, W. Photosynthetic acclimation in relation to nitrogen allocation in cucumber leaves in response to changes in irradiance. Physiol. Plant. 2011, 142, 157-169. [CrossRef] [PubMed]

28. Farquhar, G.V.; von Caemmerer, S.V.; Berry, J. A biochemical model of photosynthetic $\mathrm{CO}_{2}$ assimilation in leaves of $C_{3}$ species. Planta 1980, 149, 78-90. [CrossRef] [PubMed]

29. Sharkey, T.D.; Bernacchi, C.J.; Farquhar, G.D.; Singsaas, E.L. Fitting photosynthetic carbon dioxide response curves for $C_{3}$ leaves. Plant Cell Environ. 2007, 30, 1035-1040. [CrossRef] [PubMed]

30. Genty, B.; Briantais, J.M.; Baker, N.R. The relationship between the quantum yield of photosynthetic electron transport and quenching of chlorophyll fluorescence. Biochim. Biophys. Acta 1989, 990, 87-92. [CrossRef]

31. Kramer, D.M.; Johnson, G.; Kiirats, O.; Edwards, G.E. New fluorescence parameters for the determination of Q A redox state and excitation energy fluxes. Photosynth. Res. 2004, 79, 209. [CrossRef]

32. Hussain, M.I.; Reigosa, M.J. Allelochemical stress inhibits growth, leaf water relations, PSII photochemistry, non-photochemical fluorescence quenching, and heat energy dissipation in three $\mathrm{C}_{3}$ perennial species. J. Exp. Bot. 2011, 62, 4533-4545. [CrossRef]

33. Bian, Z.; Yang, Q.; Li, T.; Cheng, R.; Barnett, Y.; Lu, C. Study of the beneficial effects of green light on lettuce grown under short-term continuous red and blue light-emitting diodes. Physiol. Plant. 2018, 164, 226-240. [CrossRef] [PubMed]

34. Li, X.G.; Meng, Q.W.; Jiang, G.Q.; Zou, Q. The susceptibility of cucumber and sweet pepper to chilling under low irradiance is related to energy dissipation and water-water cycle. Photosynthetica 2003, 41, 259-265. [CrossRef]

35. Bian, Z.H.; Cheng, R.F.; Yang, Q.C.; Wang, J.; Lu, C. Continuous light from red, blue, and green light-emitting diodes reduces nitrate content and enhances phytochemical concentrations and antioxidant capacity in lettuce. J. Am. Soc. Hortic. Sci. 2016, 141, 186-195. [CrossRef]

36. Yang, F.; Wang, Y.; Miao, L.F. Comparative physiological and proteomic responses to drought stress in two poplar species originating from different altitudes. Physiol. Plant. 2010, 139, 388-400. [CrossRef] [PubMed] 
37. Ahmadi, A.; Baker, D. The effect of water stress on the activities of key regulatory enzymes of the sucrose to starch pathway in wheat. Plant Growth Regul. 2001, 35, 81-91. [CrossRef]

38. Elstner, E.F.; Heupel, A. Inhibition of nitrite formation from hydroxylammoniumchloride: A simple assay for superoxide dismutase. Anal. Biochem. 1976, 70, 616-620. [CrossRef]

39. Khokon, M.A.R.; Okuma, E.; Hossain, M.A.; Munemasa, S.; Uraji, M.; Nakamura, Y.; Mori, I.C.; Murata, Y. Involvement of extracellular oxidative burst in salicylic acid-induced stomatal closure in Arabidopsis. Plant Cell Environ. 2011, 34, 434-443. [CrossRef]

40. Pompella, A.; Maellaro, E.; Casini, A.; Comporti, M. Histochemical detection of lipid peroxidation in the liver of bromobenzene-poisoned mice. Am. J. Pathol. 1987, 129, 295.

41. He, X.; Mulvaney, R.L.; Banwart, W. A rapid method for total nitrogen analysis using microwave digestion. Soil Sci. Soc. Am. J. 1990, 54, 1625-1629. [CrossRef]

42. Solorzano, L. Determination of ammonia in natural water by the phenolhypochlorite method Limnol. Oceanography 1969, 14, 799-801.

43. Gangwar, S.; Singh, V.P. Indole acetic acid differently changes growth and nitrogen metabolism in Pisum sativum L. seedlings under chromium (VI) phytotoxicity: Implication of oxidative stress. Sci. Hortic. 2011, 129, 321-328. [CrossRef]

44. Jiao, D.; Huang, X.; Li, X.; Chi, W.; Kuang, T.; Zhang, Q.; Ku, M.S.; Cho, D. Photosynthetic characteristics and tolerance to photo-oxidation of transgenic rice expressing $\mathrm{C}_{4}$ photosynthesis enzymes. Photosynth. Res. 2002, 72, 85-93. [CrossRef]

45. Shapiro, B.; Stadtman, E. The regulation of glutamine synthesis in microorganisms. Annu. Rev. Microbiol. 1970, 24, 501-524. [CrossRef]

46. Majerowicz, N.; Kerbauy, G.; Nievola, C.; Suzuki, R. Growth and nitrogen metabolism of Catasetum fimbriatum (Orchidaceae) grown with different nitrogen sources. Environ. Exp. Bot. 2000, 44, 195-206. [CrossRef]

47. Aurisano, N.; Bertani, A.; Reggiani, R. Involvement of calcium and calmodulin in protein and amino acid metabolism in rice roots under anoxia. Plant Cell Physiol. 1995, 36, 1525-1529. [CrossRef]

48. Bajguz, A.; Hayat, S. Effects of brassinosteroids on the plant responses to environmental stresses. Plant Physiol. Biochem. 2009, 47, 1-8. [CrossRef]

49. Li, J.; Yang, P.; Kang, J.; Gan, Y.T.; Yu, J.H.; Calderón-Urrea, A.; Lyu, J.; Zhang, G.B.; Feng, Z.; Xie, J.M. Transcriptome analysis of pepper revealed a role of 24-epibrassinolide in response to chilling. Front. Plant Sci. 2016, 7, 1281. [CrossRef]

50. Ogweno, J.O.; Song, X.S.; Shi, K.; Hu, W.H.; Mao, W.H.; Zhou, Y.H.; Salvador, N. Brassinosteroids alleviate heat-induced inhibition of photosynthesis by increasing carboxylation efficiency and enhancing antioxidant systems in Lycopersicon esculentum. J. Plant Growth Regul. 2008, 27, 49-57. [CrossRef]

51. Ahammed, G.J.; Xia, X.J.; Li, X.; Shi, K.; Yu, J.Q.; Zhou, Y.H. Role of Brassinosteroid in Plant Adaptation to Abiotic Stresses and its Interplay with Other Hormones. Curr. Protein Pept. Sci. 2015, 16, 462-473. [CrossRef]

52. Almansa, E.M.; Espín, A.; Chica, R.M.; Lao, M.T. Nutritional response of seedling tomato plants under different lighting treatments. J. Plant Nutr. 2017, 40,467-475. [CrossRef]

53. Baker, N.R. Chlorophyll fluorescence: A probe of photosynthesis in vivo. Annu. Rev. Plant Biol. 2008, 59, 89-113. [CrossRef] [PubMed]

54. Nixon, P.J.; Michoux, F.; Yu, J.; Boehm, M.; Komenda, J. Recent advances in understanding the assembly and repair of photosystem II. Ann. Bot. 2010, 106, 1-16. [CrossRef] [PubMed]

55. Velez-Ramirez, A.I.; van Ieperen, W.; Vreugdenhil, D.; Millenaar, F.F. Plants under continuous light. Trends Plant Sci. 2011, 16, 310-318. [CrossRef] [PubMed]

56. Yang, Y.J.; Yu, L.; Wang, L.P.; Guo, S.R. Bottle gourd root stock-grafting promotes photosynthesis by regulating the stomata and non-stomata performances in leaves of watermelon seedlings under $\mathrm{NaCl}$ stress. Plant Physiol. 2015, 186, 50-58. [CrossRef]

57. Xiong, D.L.; Douthe, C.; Flexas, J. Differential coordination of stomatal conductance, mesophyll conductance and leaf hydraulic conductance in response to changing light across species. Plant Cell Environ. 2018, 41, 436-450. [CrossRef]

58. Zait, Y.; Shtein, I.; Schwartz, A. Long-Term Acclimation to Different Stress Types: Revealing Tradeoffs between Mesophyll and Stomatal Conductance. Available online: https:/www.biorxiv.org/content/10.1101/ 340786v1.full (accessed on 11 November 2019). 
59. Shahbaz, M.; Ashraf, M.; Athar, H.R. Does exogenous application of 24-epibrassinolide ameliorate salt induced growth inhibition in wheat (Triticum aestivum L.). Plant Growth Regul. 2008, 55, 51-64. [CrossRef]

60. Wang, Y.; Cao, J.J.; Wang, K.X.; Xia, X.J.; Shi, K.; Zhou, Y.H.; Yu, J.Q.; Zhou, J. BZR1 mediates brassinosteroid-induced autophagy and nitrogen starvation in tomato. Plant Physiol. 2019, 179, 671-685. [CrossRef]

61. Ma, Y.; Guo, S.; Shan, X.; Sun, J.; Wang, L.; Wang, Y.; Shu, S. Effect of exogenous 24-epibrassinolide on nitrogen assimilation of cucumber seedlings under hypoxia stress. J. Nanjing Agric. Univ. 2015, 38, 538-545.

62. Diab, H.; Limami, A.M. Metabolism upon Hypoxia Stress and Recovery: Roles of Alanine Aminotransferase (AlaAT) and Glutamate Dehydrogenase (GDH) Alternative route for nitrogen assimilation in higher plants. Plants 2016, 5, 25. [CrossRef]

63. Masclaux-Daubresse, C.; Reisdorf-Cren, M.; Pageau, K.; Lelandais, M.; Grandjean, O.; Kronenberger, J.; Valadier, M.H.; Feraud, M.; Jouglet, T.; Suzuki, A. Glutamine synthetase-glutamate synthase pathway and glutamate dehydrogenase play distinct roles in the sink-source nitrogen cycle in tobacco. Plant Physiol. 2006, 140, 444-456. [CrossRef]

64. Liu, L.; Ji, H.; An, J.; Shi, K.; Ma, J.; Liu, B.; Tang, L.; Cao, W.; Zhu, Y. Response of biomass accumulation in wheat to low-temperature stress at jointing and booting stages. Environ. Exp. Bot. 2019, 157, 46-57. [CrossRef]

65. Szabados, L.; Savouré, A. Proline: A multifunctional amino acid. Trends Plant Sci. 2010, 15, 89-97. [CrossRef] [PubMed]

66. Vardhini, B.V.; Rao, S.S.R. Amelioration of osmotic stress by brassinosteroids on seed germination and seedling growth of three varieties of sorghum. Plant Growth Regul. 2003, 41, 25-31. [CrossRef]

(C) 2019 by the authors. Licensee MDPI, Basel, Switzerland. This article is an open access article distributed under the terms and conditions of the Creative Commons Attribution (CC BY) license (http://creativecommons.org/licenses/by/4.0/). 